\title{
Private Party Immunities to Section 1983 Suits
}

\author{
Allison Hartwell Eid $\dagger$
}

In Lugar v Edmondson Oil Co., Inc., ${ }^{1}$ the Supreme Court significantly lightened the burden on plaintiffs bringing $\S 1983^{2}$ suits against private party defendants under the "joint participation" rationale of state action. The Court held that a private creditor becomes a state actor when it files a petition with the court seeking to attach a debtor's assets pursuant to a state statute that allegedly violates due process. ${ }^{3}$ The Court concluded that a plaintiff may satisfy $\S 1983$ 's state action requirement merely by showing that the private defendant "acted together with or . . . obtained significant aid from state officials." That the private creditor triggered the subsequent attachment of the debtor's property by public officers was sufficient to meet this test.

In dissent, Justice Powell characterized the majority's holding as a "disquieting example of how expansive judicial decisionmaking can ensnare a person who had every reason to believe he was acting in strict accordance with law." The majority responded by suggesting that private actors might be entitled to a good faith or qualified immunity defense similar to that enjoyed by public officials, although it expressly left the question open. ${ }^{6}$

This Comment evaluates the impact of Lugar on the joint participation doctrine in general and on the development of private party immunities in particular. Section I focuses on the state ac-

$\dagger$ A.B. 1987, Stanford University; J.D. Candidate 1991, The University of Chicago.

1457 US 922 (1982).

2 Section 1983 provides in relevant part:

Every person who, under color of any statute, ordinance, regulation, custom, or usage, of any State or Territory or the District of Columbia, subjects, or causes to be subjected, any citizen of the United States or other person within the jurisdiction thereof to the deprivation of any rights, privileges, or immunities secured by the Constitution and laws, shall be liable to the party injured in an action at law, suit in equity, or other proper proceeding for redress.

42 USC $\$ 1983$ (1982).

${ }^{3}$ Lugar, 457 US at 941.

- Id at 937.

s Id at 944 (Powell dissenting).

- Id at 942 n 23. 
tion doctrine and its justification as a shield to protect personal autonomy and private choice from constitutional scrutiny. The pre-Lugar formulation of the joint participation rationale performed this function by allowing a plaintiff to sue a private individual or entity only if the defendant intentionally conspired with a state officer. Although a private party defendant was not truly an officer of the state, the conspiratorial agreement-the "meeting of the minds"-imputed the acts of the public officer to the private individual. In Lugar, however, the Court dramatically eased $\S 1983$ 's actionable threshold by removing the conspiratorial intent requirement, opening a large area of previously protected conduct to constitutional scrutiny. Indeed, under Lugar, private party defendants who rely on seemingly valid state enactments or legitimate state authority can presumably be held liable under $\S 1983$, even when the public officers who actually commit the constitutional deprivation are immune from liability. Thus, the critical shielding function must necessarily shift from the state action to the immunity side of the equation.

Section II considers the development of the Supreme Court's public officer immunity jurisprudence, the logical source to which to turn when devising a private party immunity. The Court reformulated its public officer immunity in Harlow $v$ Fitzgerald, discarding the subjective prong of its immunity analysis and adopting a purely objective test that insulates public officers from liability unless they violate clearly established rights of which a reasonable person would know. ${ }^{7}$ The major policy consideration underlying the Court's immunity jurisprudence is the concern that officers will fail to pursue their legitimate duties vigorously if they fear liability for reasonable decisions. The objective nature of the Harlow reformulation responds to this concern by enabling courts considering immunity claims to decide the objective reasonableness of the defendant official's conduct as a matter of law and to render decisions on unmeritorious suits at the summary judgment stage of the proceedings. Finally, the Section considers the ways in which lower courts have applied the Court's public officer analysis to the private immunity context.

Section III proposes a private party immunity that adequately responds to Lugar's reformulation of the state action doctrine and comports with the rationale underlying the Court's public officer jurisprudence. Just as public officers are deterred from exercising

7457 US 800, 818 (1982). 
their discretion by fear of frivolous but protracted litigation, private parties may be deterred from relying on presumptively valid state statutes and legitimate state authority for fear of Lugar-style liability, thus creating an incentive for private individuals to resort to less desirable methods of self-help. This Comment proposes completing the state action fiction by according private individuals the full benefits of qualified immunity. Treating private individuals who act jointly with public officers as officers of the state for purposes of liability but not immunity creates a fundamental asymmetry that flouts the notion of private autonomy. Qualified immunity addresses this asymmetry by providing an objective test that shields from liability those private individuals who had no reason to know that their conduct violated established constitutional rights.

\section{The State Action Requirement}

Before turning to the precise contours of the state action doctrine, it is helpful to examine its underlying justifications.

\section{A. Maintaining the Public-Private Distinction}

The Civil Rights Act of 1871 provides a cause of action against "every person who, under color of any statute ... of any State" deprives another of his "rights, privileges, or immunities secured by the Constitution and laws ...." By fashioning a federal right enforceable in the federal courts, the Reconstruction Congress hoped to give life to the fledgling Fourteenth Amendment and its dual commands of equal protection and due process. ${ }^{\theta}$ The purpose of the statute was to deter public officials from using the badge of their authority to violate persons' constitutional rights ${ }^{10}$ and to

- 42 USC $\$ 1983$. For the full text of the statute, see note 2.

- Monroe v Pape, 365 US 167, 180 (1961), overruled on other grounds, Monell v Dept. of Social Services, 436 US 658 (1978). Congress passed $\$ 1983$ pursuant to $\S 5$ of the Fourteenth Amendment, which provides that "[t]he Congress shall have power to enforce, by appropriate legislation, the provisions of this article." The original formulation of $\S 1$ of the Civil Rights Act of 1871 was entitled "An act to enforce the Provisions of the Fourteenth Amendment to the Constitution of the United States, and for other Purposes." 17 Stat 13 (1871). As Senator Edmunds, the floor manager of the Act, told his colleagues: "[Section 1 is] so very simple and really reenact[s] the Constitution." Cong Globe, 42d Cong, 1st Sess, 569 (1871) (quoted in Lugar, 457 US at 934).

10 The Supreme Court has construed $\S 1983$ 's protection to include federal statutory rights as well. Maine $v$ Thiboutot, 448 US 1, 4 (1980). 
provide compensation and other relief to victims of constitutional deprivations when that deterrence failed. ${ }^{11}$

Not surprisingly, the vast majority of claims filed under the statute name public officers and entities as defendants. In fact, the Fourteenth Amendment expressly proscribes only state action: the deprivation of rights must be "under color of" the law. ${ }^{22}$ Purely private conduct is thus not actionable. ${ }^{13}$ In limiting $\S 1983$ to deprivations of constitutional rights by state actors, the Reconstruction Congress recognized that the Constitution protects private citizens from conduct by the state, not conduct by other citizens, no matter how discriminatory or wrongful that conduct might be. ${ }^{14}$

The distinction between the public arena, which is subject to constitutional constraints, and the private arena, which is shielded from such limitations, can be traced to the nation's founding. Indeed, "the people of the newly formed United States were determined to place specific strictures on the national government." ${ }^{15} \mathrm{~A}$ constitution is by its nature a two-way compact between a citizenry and the state, limiting the state's right to intrude on a vast area of private conduct. ${ }^{18}$ The Lugar Court reaffirmed this rationale and viewed adherence to the state action requirement as a way of "preserv[ing] an area of individual freedom by limiting the reach of federal law and federal judicial power. . . . A major consequence is to require the courts to respect the limits of their own power as directed against state governments and private interests." 17 By excluding private action from the reach of the Constitution's prohibitions, the state action requirement provides a zone of

11 Carey v Piphus, 435 US 247, 253-57 (1978).

12 The Court in Lugar concluded that the "under color of" state law requirement of $\S 1983$ and the state action requirement of the Fourteenth Amendment are coextensive when the $\S 1983$ suit alleges a violation of a right protected by the Fourteenth Amendment. 457 US at 935 n 18. See generally Sheldon H. Nahmod, Civil Rights and Civil Liberties Litigation: The Law of Section 1983 \& 2.06 at 85 (McGraw-Hill, 2d ed 1986) ("Civil Rights Litigation").

${ }^{23}$ See, for example, Jackson v Metropolitan Edison Co., 419 US 345, 349 (1974) (finding no state action where heavily regulated utility company terminated service to customers).

" See, for example, the Civil Rights Cases, 109 US 3 (1883); NCAA v Tarkanian, 488 US 179, $109 \mathrm{~S} \mathrm{Ct} 454,461$ (1988). The exception is the Thirteenth Amendment's prohibition against slavery, which governs private as well as public conduct. Civil Rights Cases, 109 US at 20.

${ }_{15}$ William M. Burke and David J. Reber, State Action, Congressional Power and Creditors' Rights: An Essay on the Fourteenth Amendment, 46 S Cal L Rev 1003, 1013 (1973).

${ }^{28}$ See James M. Dolliver, The Washington Constitution and "State Action": The View of the Framers, 22 Willamette L Rev 445, 447-48 (1986).

${ }^{12}$ Lugar, 457 US at 936-37. 
private autonomy and free choice that is "basic under any conception of liberty."18

The dichotomy between private and public conduct is far from absolute, however. ${ }^{19}$ The Court has indicated that when private conduct is closely linked to public conduct, a private individual may act "under color of" state law even though he is not an officer of the state. ${ }^{20}$ When both private and public entities are involved, the court must decide when the "private conduct ought to be treated as if it were governmental conduct."21 When a plaintiff challenges purely public conduct, the inquiry into the public-private connection is unnecessary; the public officers provide the requisite state action because they "carry a badge of authority of a State and represent it in some capacity, whether they act in accordance with their authority or misuse it."22 But often public and private action are closely intermingled, presenting courts with a difficult task of characterization.

\section{B. The Supreme Court's State Action Jurisprudence}

Purely private conduct is not subject to $\S 1983$ unless there is "something more" to transform it into public conduct. ${ }^{28}$ The Court has developed various tests to determine when this additional element exists. The "public function" test, for example, identifies conduct as "public" when a private party performs a function that has been " "traditionally the exclusive prerogative of the state." "24 The "nexus" or "symbiosis" test isolates situations in which a private actor enjoys an interdependent relationship with the state. ${ }^{25}$ 1988).

${ }^{18}$ Laurence H. Tribe, American Constitutional Law $\$ 18-2$ at 1691 (Foundation, $2 \mathrm{~d}$ ed

10 This Comment uses "public" conduct to denote conduct by a government officer or other government employee.

${ }^{20}$ Adickes v S.H. Kress \& Co., 398 US 144, 152 (1970).

${ }^{21}$ Nahmod, Civil Rights Litigation $\$ 2.04$ at 78 (emphasis in original) (cited in note 12).

${ }^{22}$ Monroe, 365 US at 172.

28 Lugar, 457 US at 939.

24 Blum v Yaretsky, 457 US 991, 1005 (1982) (emphasis added), citing Jackson v Metropolitan Edison Co., 419 US 345, 353 (1974). See also Marsh v Alabama, 326 US 501 (1946) (holding that a private corporation that owned a town's roads and sidewalks could not prevent an individual from using the roads and sidewalks for the distribution of religious materials).

${ }^{28}$ Burton v Wilmington Parking Authority, 365 US 715 (1961) (finding state action under the symbiosis test where municipal authority received money from a space it leased to a restaurant that discriminated against black customers); Jackson, 419 US at 349 (finding no state action where heavily regulated utility company terminated service to customers on the ground that there failed to be "a sufficiently close nexus between the State and the challenged activity of the regulated entity so that the action of the latter [could] be fairly treated as that of the State itself."). 
The "state compulsion" test attaches liability to private conduct when a state law or custom compels the action of the private party. ${ }^{28}$ And finally, the "joint participation" test identifies those cases in which a private party conspires or acts in concert with a state officer. ${ }^{27}$

The Court has acknowledged, however, that the state action doctrine is not tied to tests and categories. Instead, the recognition of state action depends upon an ad hoc analysis of the facts of each case. ${ }^{28}$ The Court seems to evaluate the facts, measure the strength of the link between the private and public conduct, and then attach a label to the result it reaches that most appropriately describes the connection. Plaintiffs often attempt to shoehorn their case into several different theories with the hope that the Court will adopt one of them. ${ }^{29}$ Most commentators agree that the state action doctrine is essentially malleable and unpredictable. ${ }^{30}$ As one observer put it, it is the "anti-doctrine." 31

The following overview of the Supreme Court's pre-Lugar joint participation jurisprudence suggests that the Court had limited the category of actionable cases to those in which private parties conspired with state officers. The discussion of Lugar's trans-

\footnotetext{
${ }^{28}$ Adickes, 398 US at 170. Adickes articulated two distinct state action theories: the "state compulsion" test and the "joint participation" test. The case involved a white Northern woman who was refused service at a Southern lunchcounter because she seated herself with a group of black students. Under the state compulsion theory, the Court held that the plaintiff could maintain a $\$ 1983$ action if she could show she was refused service "because of a state-enforced custom of segregating the races in public restaurants." Id at 171. For a discussion of Adickes in the joint participation context, see text at notes 33-37.

${ }^{27}$ Id at 152 . According to one treatise, the joint participation rationale has been the "exception" to the trend of "cut[ting] back on findings of state action." Nahmod, Civil Rights Litigation $\S 2.01$ at $73-74$ (cited in note 12).

${ }^{28}$ Lugar, 457 US at 939.

${ }^{28}$ For example, in NCAA $v$ Tarkanian, 488 US 179 (1988), the plaintiff alleged under a "public function" theory that the University of Nevada-Las Vegas, a public entity, had delegated to the National Collegiate Athletic Association, a private organization, the authority to govern the school's athletic programs. Id at 191-92. He also asserted under the "nexus" theory that the NCAA's power was so great that the school had no choice but to obey its commands. Id at 198-99. Finally, he claimed that UNLV and the NCAA were "joint participants" in the investigation of UNLV's athletic programs. Id at $196 \mathrm{n}$ 16. Five members of the Court rejected all three theories and found no state action. Id at 191-99. The fourmember dissent, however, embraced the plaintiff's "joint participation" rationale. Id at 200 (White dissenting).

${ }^{\text {so }}$ See, for example, Comment, Communications Workers v. Beck: Supreme Court Throws Unions Out on Street, 57 Fordham L Rev 665 (1989); Robert J. Glennon, Jr. and John E. Nowack, A Functional Analysis of the Fourteenth Amendment "State Action" Requirement, 1976 S Ct Rev 221; Christopher D. Stone, Corporate Vices and Corporate Virtues: Do Public/Private Distinctions Matter?, 130 U Pa L Rev 1441, 1484 n 156 (1982). s1 See Tribe, American Constitutional Law § 18-1 at 1688-91 (cited in note 18).
} 
formation of the joint participation doctrine concludes that the opinion shifted the state action shielding function to the immunity side of the equation.

1. The Court's pre-Lugar joint participation jurisprudence.

The joint participation theory finds its roots in "traditional principles of agency, partnership, joint venture and the like."32 The Supreme Court first recognized the rationale in Adickes $v$ S.H. Kress \& Co., ${ }^{33}$ in which a white Northern woman who had seated herself with a group of black students at a Southern lunchcounter was arrested for vagrancy after she left the store. In her suit, she alleged that the store manager conspired with the arresting officer to cause the arrest. The Court held that it was necessary for the plaintiff to show the conspirators had "a 'meeting of the minds' and thus reached an understanding" to deprive the plaintiff of her civil rights, though the plaintiff could make the necessary showing through circumstantial evidence of agreement. ${ }^{34}$

In Adickes, the police officer's position as an agent of the state satisfied the state action requirement. The "meeting of the minds," or conspiratorial element, then provided the mechanism by which the acts of the public officer could be imputed to the private defendant..$^{35}$ Under traditional principles of conspiratorial accountability, each conspirator is jointly and severally liable for the others' acts done in furtherance of the conspiracy. ${ }^{38}$ The private defendant in Adickes thus acted "under color of" law when he conspired with the officer to bring about the deprivation. ${ }^{37}$

\footnotetext{
${ }^{32}$ Nesmith v Alford, 318 F2d 110, 126 (5th Cir 1963) (facts substantially identical to Adickes).

s3 398 US 144 (1970).

s4 Id at 157-58. In an affidavit, the store manager admitted that-in accordance with a prearranged plan-he signaled the waitress not to serve the plaintiff. It was the plaintiff's theory that the store manager and other employees had a similar signaling arrangement with the local police. Id at 153-58.

ss Id at 158. See also Gomez v Florida State Employment Service, 417 F2d 569, 578 (5th Cir 1969) (conspiracy charge provides the means by which the court can hold each defendant accountable for the acts of others); Note, Section 1983 Liability of Private Actors who Conspire with Immune State Officials, 80 Colum L Rev 802, 806 (1980) ("Under the rationale of Adickes, the state action attributable to a government official is imputed to a private citizen conspiring with the official.").

36 See 16 Am Jur 2d Conspiracy $\$ 56$ at 271 (1979).

37 The Adickes court based its decision on an earlier case alleging criminal conspiracy. See United States $v$ Price, 383 US 787 (1966) (interpreting 18 USC $\$ 241$ to include protection of rights secured by the Fourteenth Amendment).
} 
The Court reaffirmed the Adickes formulation of the joint participation analysis in Dennis $v$ Sparks. ${ }^{38}$ In Dennis, the plaintiffs claimed that an injunction enjoining them from extracting oil from their land violated due process because it had been "corruptly issued" as the result of a conspiracy between a state judge and several private individuals. The Court sustained the plaintiffs' cause of action on the theory that the private party conspirators acted under color of law. ${ }^{39}$

Thus, in order to sustain a cause of action under the joint participation theory as developed in Adickes and Dennis, the plaintiff had to show the existence of a conspiracy in which the participants reached an agreement to violate his constitutional rights. As the Court noted in Adickes: "[A] private party involved in . . . a conspiracy, even though not an official of the State, can be liable under § 1983."40 Prior to Lugar, a negligent or unintentional violation of constitutional rights was not actionable under the joint participation rationale. ${ }^{41}$ Some degree of conspiratorial intent or bad faith was necessary for the acts of the public officer to be imputed to the private individual, thus transforming the private individual into a state actor. ${ }^{42}$

${ }^{38} 449$ US 24 (1980).

39 Id at 26, 29.

40398 US at 152.

42 Although neither Adickes nor Dennis discussed the intent requirement of civil conspiracy, both cases were premised on traditional conspiracy doctrine in which unintentional deprivations of rights are not actionable. It is hornbook law that a civil conspiracy is a combination of two or more persons acting in concert to commit an unlawful act, or to commit a lawful act by unlawful means, the principal element of which is an agreement between the parties to inflict a wrong or injury upon another. See, for example, Hampton $v$ Hanrahan, 600 F2d 600, 620-21 (7th Cir 1979); Rotermund v United States Steel Corp., 474 F2d 1139, 1145 (8th $\mathrm{Cir} 1973$ ). Indeed, civil conspiracy requires "an intentional interference with a right without lawful justification." 16 Am Jur 2d Conspiracy $\S 50$ at 268 (cited in note 36$)$.

Thus, the requirement of a conspiratorial agreement-or bad faith—is the converse of the good faith immunity doctrine. Whereas an agreement under Adickes required defendants to reach a meeting of the minds to violate the constitutional rights of another, good faith immunity protects defendants from liability when their conduct does not violate clearly established constitutional rights of which a reasonable person would know. See, for example, Lenard $v$ Argento, 699 F2d 874 (7th Cir 1983) (police officers could not be liable for conspiracy under $\$ 1983$ because they arrested plaintiff in good faith on a showing of probable cause). One leading treatise on $\S 1983$ notes that "Lugar does not in fact involve joint action in the usual agreement or conspiratorial sense [such as the terminology was used in Adickes and Dennis], but rather consecutive private and public conduct . . . " Martin A. Schwartz and John E. Kirklin, Section 1983 Litigation: Claims, Defenses and Fees \& 5.13 at 110 (John Wiley \& Sons, 1986).

${ }^{42}$ Although the Court in Lugar held that there was no bad faith conspiracy requirement, it seemed to reinstate the requirement six years later in Tarkanian. Asserting that the NCAA and UNLV acted jointly, the four-member dissent would have held the NCAA 
2. Lugar's reformulation of the joint participation rationale.

a) The facts and holding. Edmondson Oil Co., a small wholesale oil dealer in Southside, Virginia, had supplied more than $\$ 40,000$ in products and merchandise to Lugar, a truckstop operator. When Lugar failed to pay his bill, Edmondson sued Lugar in state court to recover the debt. ${ }^{48}$ Fearing that Lugar might dissipate his assets before the debt could be collected, Edmondson also filed a petition with the county clerk seeking prejudgment attachment of a portion of Lugar's property. Edmondson's petition relied on a Virginia prejudgment attachment statute in use for more than 150 years. The county sheriff subsequently executed the writ of attachment and seized Lugar's property. ${ }^{44}$

Lugar then brought a $\S 1983$ suit naming Edmondson Oil as the sole defendant, alleging that Edmondson acted "jointly" with the sheriff and the clerk to deprive him of his property without due process of law in violation of the Fourteenth Amendment. ${ }^{45}$ The plaintiff claimed that the prejudgment attachment statute on which Edmondson relied violated the procedural due process protections established by the Court in the garnishment and prejudgment attachment context. ${ }^{46}$ Despite the fact that Edmondson Oil had relied on a presumptively valid state law without a hint of bad faith, the Court held that Lugar stated a valid § 1983 claim. In concluding that Edmondson's filing of the attachment petition triggered a constitutionally invalid attachment proceeding, the Court dramatically lowered the actionable threshold for $\S 1983$ suits.

b) Lowering the actionable threshold. Adickes and Dennis placed the actionable threshold for $\S 1983$ joint participation suits at conspiratorial or collusive private behavior. Using traditional conspiracy principles of accountability, the Court separated this bad faith conduct from other private conduct and subjected only

liable as a state actor under the joint participation test of Adickes and Dennis. 488 US at 200 (White dissenting). In rejecting this argument, the majority distinguished Adickes and Dennis, noting that "in this case there is no suggestion of any impropriety respecting the agreement between the NCAA and UNLV." Id at $197 \mathrm{n} 17$ (emphasis added). Yet, as discussed below, there was no hint of impropriety in the "agreement" between Edmondson Oil and the clerk of the county court who issued the writ of attachment or the sheriff who executed the writ.

43 Lugar, 457 US at 924, $944 \mathrm{n} 1$ (Powell dissenting).

44 Id at 924-25.

45 Id at 925 .

46 Id at 927. See Sniadach v Family Finance Corp., 395 US 337 (1969); Fuentes $v$ Shevin, 407 US 67 (1972); Mitchell v W.T. Grant Co., 416 US 600 (1974); North Georgia Finishing, Inc. v Di-Chem, Inc., 419 US 601 (1975). 
the former to constitutional scrutiny. Private conduct falling below that line was shielded from constitutional scrutiny, although it might well have been subject to liability under state law. ${ }^{47}$

Lugar's complaint, however, contained no allegation that Edmondson conspired or colluded with any county official. Nor was any public official joined in the lawsuit. Nothing in the record suggested that Edmondson did anything but rely on a presumptively valid state attachment statute. To suggest that Edmondson and the clerk reached a "meeting of the minds" on the subsequent attachment seems untenable at best. Nonetheless, the Court held that Edmondson could be held liable for the subsequent deprivation performed by the public officials. With one quick stroke the Court thus reduced the requisite degree of joint participation from conspiracy to a simple filing of papers with the county court.

By removing the conspiracy requirement from the joint participation doctrine, the Lugar Court placed into a single category all private defendants who invoke unconstitutional state conduct, regardless if they acted in good or bad faith. The Court set forth a two-part test for finding state action:

First, the [unconstitutional] deprivation must be caused by the exercise of some right or privilege created by the State or by a rule of conduct imposed by the State or by a person for whom the State is responsible. . . . Second, the party charged with the deprivation must be a person who may fairly be said to be a state actor. This may be because he is a state official, because he has acted together with or has obtained significant aid from state officials, or because his conduct is otherwise chargeable to the State. ${ }^{48}$

The first prong-the "state act" component-addresses the subsequent state act triggered by the private actor. Presumably all unconstitutional deprivations committed by the state would fall into this category, including illegal injunctions (Dennis), illegal arrests (Adickes), and enforcement of unconstitutional prejudgment attachment statutes (Lugar), ${ }^{48}$ regardless of the public officer's motivations.

47 For example, the plaintiff might have brought a common law malicious prosecution suit against Edmondson, assuming the facts warranted it. Lugar, 457 US at 943 (Burger dissenting).

48 Id at 937.

49 One commentator has suggested that the Court may have actually tightened the state action requirement in Lugar because now "a plaintiff cannot bring a section 1983 suit against a private party who instigates official misbehavior. . . . Lugar may simply bar the 
The second prong of the Lugar test established the actionable threshold that replaces the conspiracy requirement. A private individual now need only act together with or obtain "significant aid" from public officials to accomplish the unconstitutional deprivation. The Lugar reformulation ignores culpability, sweeping in both the "good faith" triggers (such as the defendant in Lugar) and the "bad faith" triggers (such as the defendants in Dennis and Adickes) with identical allegations of joint participation. In response to dissenter Justice Powell's concerns that the Court was applying the same degree of culpability to fundamentally different kinds of conduct, the majority declared that it was limiting its holding to "the particular context of prejudgment attachment,"so in effect suggesting that only bad faith triggers and good faith creditor triggers will be grouped in the same category. It is unclear

victim of such misbehavior from getting to the 'deep pocket' of the private party." The Supreme Court-1981 Term, 96 Harv L Rev 4, 244, 245-46 (1982) (emphasis added). The commentator came to this conclusion because the first prong of the Lugar analysis requires the defendant to have invoked a state policy or law. According to the commentator, this requirement would prevent plaintiffs from bringing claims against a private defendant who instigated public misuse of the statutory scheme because only the statute-and not the misuse of the statute-could be attributed to the state. The right to sue the misbehaving official directly would remain, however, under the "abuse of authority doctrine" of Monroe $v$ Pape, 365 US 167 (1961).

This reading of the Lugar opinion is dubious at best. It fails to explain cases such as Dennis, in which a private party was held liable under $\$ 1983$ for conspiring with a judge who misused his authority-a conspiracy that was not "state policy." The commentator's reading of the first prong ignores the last phrase, which notes that deprivations can be caused by a state policy or by "a person for whom the State is responsible," i.e., any state official acting within his authority or abusing his authority. The commentator's suggestion has also been refuted by post-Lugar cases such as Howerton $v$ Gabica, which involved "using the police to facilitate an illegal repossession." 708 F2d 380, 384 (9th Cir 1983) (emphasis in original). Howerton is discussed in the immunity context in Section III. See text at notes 96-99.

so Lugar, 457 US at $939 \mathrm{n} 21$. Like many such "limited holding" admonitions, this particular one has been ignored by many courts and commentators. See, for example, Sable Communications of California, Inc. v Pacific Telephone and Telegraph Co., 890 F2d 184, 189 (9th $\mathrm{Cir} 1989$ ) (phone company acted under color of law when it invoked state regulatory procedure to disconnect sexually explicit message service as long as company "acted jointly with, or under compulsion from, state officials under a procedural scheme created by the state"); and Howerton, 708 F2d at 384 (state action found when landlord repeatedly requested police assistance in effecting eviction of plaintiffs). And as one treatise has suggested, "[i]t is unclear ... why Lugar should not apply to the invocation of legal procedures other than prejudgment attachment that require the participation of public officials for their enforcement." Schwartz and Kirklin, Section 1983 Litigation $\$ 5.13$ at 110 (cited in note 41). But see Davis Oil Co. v Mills, 873 F2d 774, 780 (5th Cir 1989) (low threshold of establishing joint participation should be "confined to the context of ex parte prejudgment proceedings"). 
why the Court singled out creditors for unfavorable treatment under § $1983 . .^{\text {s1 }}$

The end result is that the mechanism of joint participation has enabled plaintiffs to bring $§ 1983$ suits against good faith triggers, bad faith triggers, and all triggers in between. ${ }^{.2}$ The only conduct that the Court specifically placed on the nonactionable side of the line was private abuse of a state statutory scheme, since such conduct "could not be ascribed to any governmental decision." For example, Lugar could not have sued Edmondson Oil under $\S 1983$ had the state statute been constitutional-even if Edmondson filed its attachment petition merely to harass Lugar-because the decision to file was a purely private one, and the subsequent attachment by public officers was executed properly. The Court specifically noted that private abuse of a statutory scheme does not fall within the abuse of authority doctrine of Monroe $v$ Pape, which held that misbehavior by a public official was conduct under color of law attributable to the state. ${ }^{54}$ Thus, private party defendants under Lugar can be held liable if they properly invoke an unconstitutional statute but not if they improperly invoke a constitutional statute. ${ }^{5 s}$ Surely it is a perverse result when acting in strict accordance with a statutory scheme is a necessary prerequisite-not a bar-to liability.

c) Shifting the focus to private immunities. The Lugar majority acknowledged that the Court might be treading far into the realm of traditionally "private" conduct, but decided

this problem should be dealt with not by changing the character of the cause of action but by establishing an affirmative defense. A similar concern is at least partially responsible for the availability of a good-faith defense, or qualified immunity,

s1 The Court seemed to confirm its differential treatment of creditors in Tarkanian, a non-creditor case in which it refused to hold a private entity liable under the joint participation rationale in the absence of a bad faith or "improper" agreement. See note 42.

${ }^{52}$ The "in between" category seems to have caused a good deal of confusion. See, for example, Collins $v$ Womancare, 878 F2d 1145, 1154 (9th Cir 1989) (requiring a "substantial degree of cooperative action" between private and public defendants for liability under Lugar's joint participation rationale).

${ }^{33}$ Lugar, 457 US at 938.

54 Id at 940, citing Monroe $v$ Pape, 365 US 167 (1961). For a more detailed discussion of the abuse of authority doctrine, see note 49.

Bs See Long v Citizen's Bank \& Trust Co. of Manhattan, Kansas, 563 F Supp 1203, 1215 (D Kan 1983): "Only when the private party creditor has properly invoked the statutory scheme and met its requirements may the deprivation of a property interest properly be traced to that scheme, and only then would the injured plaintiff have standing to challenge the constitutionality of that scheme." 
to state officials. We need not reach the question of availability of such a defense to private individuals at this juncture. ${ }^{56}$

Despite words to the contrary, the Court had in fact changed the prima facie case of $\S 1983$, creating the "problem" to which it referred. The Court in effect transformed a prima facie pleading requirement of "bad faith" into an affirmative defense of "good faith." actionable side of the line in the first instance, and then puts the burden on defendants to prove that their particular conduct should fall on the nonactionable side of the line. In a post-Lugar world without private party immunities, the good faith defendants cannot cross into protected territory. Ironically, private party defendants can be held liable while the public officer defendants who actually committed the constitutional deprivation escape liability by claiming official immunity.

Shifting the burden of showing intent onto the private defendants is more significant than merely tinkering with pleading requirements, however. It signals a major doctrinal shift in $\S 1983$ jurisprudence: in future joint participation cases, immunity to suit, not the state action requirement, will provide the mechanism by which the Court can protect the zone of good faith private conduct from constitutional scrutiny. Indeed, the state action doctrine provides the critical distinction between the public sector, which is subject to the strictures of the Constitution, and the private sector, which is not. ${ }^{58}$ The doctrine serves as the gatekeeper between the two; it attempts to distinguish certain private conduct that uses government power to achieve improper goals from the remainder of private conduct that must be shielded from government intrusion. By eliminating the conspiracy requirement from the joint participation test, the Court shifted the emphasis in its state action jurisprudence, transferring the shielding function from the plaintiff's prima facie case to the defendant's defenses to suit.

\footnotetext{
${ }^{86}$ Lugar, 457 US at $942 \mathrm{n} 23$.

${ }^{87}$ For example, such an implicit pleading requirement can be found in Dennis, where the private defendants were alleged to have been involved in a "corrupt conspiracy involving the bribery of [a] judge." 449 US 24, 28 (1980). The private defendants claimed that, because judges are immune from $\S 1983$ suits, the plaintiffs could not make the requisite showing of state action; the defendants had not conspired with any person against whom a valid $\S 1983$ suit could be brought. In rejecting the defendants' theory of "derivative immunity," the Court never mentioned the possibility that the defendants might avail themselves of a good faith or qualified immunity defense independent of the derivative immunity argument. That omission may be attributable to the fact that the defendants' bad faith was evident from the pleadings and circumstances of the case.

ss Erwin Chemerinsky, Rethinking State Action, $80 \mathrm{Nw}$ U L Rev 503, 504 (1985). See text at notes 12-14.
} 


\section{Immunity to Sectron 1983 Suits}

The Supreme Court has not provided an analytical framework that directly addresses private party immunity. It has, however, developed an extensive jurisprudence focusing on immunities for public officers who are sued under $\S 1983^{59}$.in their individual capacities. ${ }^{60}$ Lower courts have drawn from this body of authority when faced with questions of private party immunity.

Essentially, the Court performs two distinct inquiries in every public officer immunity case. First, it determines the degree of immunity-qualified or absolute-that a particular public official is entitled to assert. Once the degree of immunity is established, the Court examines the merits of the claim to determine whether the defendant deserves immunity protection. This Section addresses these two steps of the analysis as they have been developed by the Court and then turns to the public policy considerations underlying public officer immunity.

\section{A. The Supreme Court's Immunity Jurisprudence}

1. Determining the entitlement to claim absolute or qualified immunity.

The text of $\S 1983$ is silent on the issue of official immunities to suit. On its face, it subjects to liability "[e]very person who, under color of any statute" deprives another of constitutional rights. ${ }^{61}$ Whether Congress's failure to include immunities should be viewed as a deliberate abrogation of such immunities or a mere oversight by the statute's drafters is a matter of scholarly debate. ${ }^{62}$

69 The Court has held that its immunity analysis is identical for $\S 1983$ and the federal analog of $\S 1983$, the so-called Bivens action (named after the case that recognized the cause of action, Bivens $v$ Six Unknown Named Agents of Federal Bureau of Narcotics, 403 US 388 (1971)). See Butz v Economou, 438 US 478, 504 (1978) (Bivens claim). Bivens suits allow plaintiffs to sue federal officers for violations of constitutional rights.

${ }^{80}$ Public officials may be sued either in their official or individual capacities. When a state officer is a named defendant in an official capacity suit, the plaintiff is in reality suing the state that employs the officer. Thus, the appropriate source of immunity protection is the Eleventh Amendment. In an individual capacity suit, the plaintiff is actually suing the officer; public officer immunities protect the defendant from personal liability. The individual capacity suit is most relevant to this Comment. For a general discussion of the distinction between the two types of suits, see Nahmod, Civil Rights Litigation $\$ 6.14$ at 374-76 (cited in note 12).

61 For the full text of the statute, see note 2. Under $\S 1983$, the term "person" includes state and local officers, local governmental entities, and private individuals and entities acting under color of law. It does not include states or state agencies. See Schwartz and Kirklin, Section 1983 Litigation $\S 5.2$ at 92 (cited in note 41 ).

${ }^{6}$ See generally Richard A. Matasar, Personal Immunities Under Section 1983: The 
The Court has stated, however, that the forty-second Congress in 1871 intended to incorporate into the statute the common law immunities existing at the time. ${ }^{68}$

Until recently, the Court characterized its process of determining the degree of immunity to which a particular official is entitled as a "careful inquiry into considerations of both history and policy." Using the common law as an anchor for its discussion of public policy, the Court took pains to avoid the appearance of "judicial fiat." "es This dual history/public policy inquiry led the Court to accord varying degrees of protection to different public officers, including absolute immunity, which shields the officer from all claims arising out of official conduct, ${ }^{68}$ and qualified immunity, which protects officials from liability for reasonable acts. ${ }^{67}$ For example, in Pierson $v$ Ray, the Court held that judges may claim absolute immunity from suit because such protection met both prongs of the test: absolute immunity was solidly entrenched at common law, and is necessary to shield judges from dissatisfied parties who would "hound [them] with litigation charging malice or corruption."

In its most recent cases, however, the Court has disposed of the individualized historical inquiry and has recognized an acrossthe-board entitlement to qualified immunity for all government officials performing discretionary functions. ${ }^{69}$ In Anderson $v$ Creighton, Justice Scalia noted that the Court in its recent decisions "completely reformulated qualified immunity along principles not

Limits of the Court's Historical Analysis, 40 Ark L Rev 741 (1987).

es See Owen v City of Independence, 445 US 622, 637 (1980).

ot City of Newport v Fact Concerts, Inc., 453 US 247, 259 (1981). At least one scholar has challenged the Court's characterization of its inquiry, asserting that its use of history in the public immunity context is "a mask for its policymaking." See Matasar, 40 Ark L Rev at 744 (cited in note 62).

os Imbler v Pachtman, 424 US 409, 421 (1976).

so See, for example, Tenney $v$ Brandhove, 341 US 367, 376 (1951) (legislators); Pierson $v$ Ray, 386 US 547, 553-54 (1967) (judges); and Imbler, 424 US at 427 (prosecutors).

67 See Wood v Strickland, 420 US 308, 318 (1975) (local school board members); Pierson, 386 US at 557 (local police officers); Procunier v Navarette, 434 US 555, 561 (1978) (prison officials and officers); O'Connor v Donaldson, 422 US 563, 576-77 (1975) (superintendent of state hospital); and Scheuer v Rhodes, 416 US 232, 247 (1974) (state governor and other executive officers).

88 386 US at 554-55.

09 One commentator has criticized this recent ahistorical inquiry, contending that it ignores the common law distinction between absolute and qualified immunity and accords officers who deserve only qualified immunity the equivalent of absolute immunity at common law. See Laura Oren, Immunity and Accountability in Civil Rights Litigation: Who Should Pay?, 50 U Pitt L Rev 935, 937-38 (1989). 
at all embodied in the common law." Because all public officials performing discretionary tasks may now claim qualified immunity from suit, the historical inquiry is limited to cases in which an official's immunity can be "bumped up" to absolute immunity.

If a particular official is entitled to claim absolute immunity, the judicial inquiry ends regardless of the strength of the plaintiff's claim. If the official is accorded qualified immunity, however, the inquiry shifts to the merits of the immunity claim.

2. Determining the merits of the claim.

Although the courts often use the terms "good faith defense" and "qualified immunity" interchangeably, there are significant distinctions between the two. Contemporary immunities are rooted in the common law precept that "the King can do no wrong." "An immunity is more than a mere defense; it is an entitlement not to stand suit or face the burdens of litigation at all. ${ }^{22}$ With this in mind, the Court in recent years has substantially changed the nature of its inquiry into the merits of immunity claims.

Until its 1982 decision in Harlow $v$ Fitzgerald, ${ }^{73}$ the Court conducted both a subjective and an objective inquiry into the motivations of the defendant official, first determining whether the defendant acted in subjective good faith, and then evaluating whether that good faith belief was objectively reasonable. ${ }^{74} \mathrm{Be}-$ cause of the fact-based nature of the inquiry, a determination on the merits could be made only after trial, or on summary judgment in the unlikely event the defendant could show that there was no material dispute as to the facts of the case. ${ }^{75}$

In Harlow, the Court discarded the subjective good faith element of its qualified immunity analysis, holding that "governmental officials performing discretionary functions generally are shielded from liability for civil damages insofar as their conduct does not violate clearly established statutory or constitutional rights of which a reasonable person would have known." ${ }^{\text {"76 }}$ Clarify-

70 483 US 635, 645 (1987) (Bivens claim).

${ }_{71}$ W. Page Keeton, et al, Prosser and Keeton on The Law of Torts $\$ 131$ at 1033 (West, 5th ed 1984).

${ }^{72}$ Harlow v Fitzgerald, 457 US 800, 813-19 (1982) (Bivens claim).

${ }^{73}$ Id.

74 See, for example, Wood, 420 US at 321 .

75 See Harlow, 457 US at 815-17.

70 Id at 818. For an extensive discussion of the development of the "clearly established law" requirement, see Schwartz and Kirklin, Section 1983 Litigation \$ 7.13 at 168-69 and 1990 Supp at 167-71 (cited in note 41). 
ing the nature of the objective inquiry, the Court in a later decision noted that an immunity should be denied only when a right is "sufficiently clear that a reasonable official would understand that what he is doing violates that right. ... [I]n the light of preexisting law the unlawfulness [of the official's action] must be apparent."

Finally, the Harlow court added a limited exception to the purely objective nature of the immunity inquiry. Even if a court finds that the right was "clearly established" to the extent that a reasonable officer should have known about it, the officer may escape liability if he "claims extraordinary circumstances and can prove that he neither knew nor should have known of the relevant legal standard."78 Despite adding the subjective element-the "neither knew" language- the court cautioned that even under the "extraordinary circumstances" exception, the immunity "would turn primarily on objective factors." According to the Court, the emphasis on the objective inquiry reflected its desire to foster early dismissal of insubstantial claims and to avoid disruption of government business. ${ }^{80}$

3. Policies underlying public officer immunity.

Although the Court has changed the contours of its immunity analysis to a certain degree, it has consistently based its decisions on the same policy considerations. The first of those considerations has already been mentioned: public officials should spend their time doing their jobs, not defending against frivolous lawsuits. This consideration led the Court to adopt the Harlow test, which enables courts to dispose of the immunity issue early in the litigation process. Indeed, the objective nature of the inquiry allows courts to limit the scope of discovery, ${ }^{81}$ decide as a matter of law whether the constitutional right in question was "clearly established,"

77 Anderson, 483 US at 640.

7. Harlow, 457 US at 819.

79 Id. One treatise has suggested that an official might be able to claim entitlement to the "extraordinary circumstances" exception if he relied on the advice of counsel or if he was merely a subordinate employee following the orders of his superiors. See Schwartz and Kirklin, Section 1983 Litigation $\$ 7.12$ at $167-68$ (cited in note 41 ).

so Harlow, 457 US at 819.

s1 See Anderson, 483 US at 646 n 6 . Whether a $\S 1983$ plaintiff may conduct any discovery is an open question. Some courts have refused to allow discovery prior to the resolution of the immunity issue; others have ordered at least some discovery. See Kit Kinports, Qualified Immunity in Section 1983 Cases: The Unanswered Questions, 23 Ga L Rev 597, 642-61 (1989), especially 642-43 and nn 186 \& 187.

See Mitchell v Forsyth, 472 US 511, 526 (1985) (Bivens claim) (objective standard 
mary judgment..$^{83}$ In addition, the defendant public official can appeal an order denying immunity immediately, before the trial has begun. ${ }^{84}$

The Court has also been concerned that frivolous lawsuits deter public officers from vigorously executing their duties for fear of incurring personal liability for every decision they make. ${ }^{85}$ As the court noted in Harlow, "there is the danger that fear of being sued will 'dampen the ardor of all but the most resolute, or the most irresponsible [public officials], in the unflinching discharge of their duties." "B8 Without the protection of immunity, officials might shrink from important decisions and rely on formalism instead of informed judgment. ${ }^{87}$ Indeed, when an official's duties require action where clearly established rights are not implicated, the Court has noted that the public interest would be "better served by action taken 'with independence and without fear of consequences." "88 And the Court has suggested that not only will the threat of liability deter public officers from exercising their discretion with the appropriate degree of vigor, it will discourage citizens from accepting public office in the first place. ${ }^{89}$

Of course, these considerations supporting immunity must be balanced with the need to deter constitutional deprivations and to compensate victims when that deterrence fails. Indeed, "an action for damages may offer the only realistic avenue for vindication of constitutional guarantees." 90 Some have suggested that the Court has eviscerated constitutional rights by giving officials too much protection. ${ }^{91}$ Regardless of the precise balance between liability

facilitates summary judgment because the court need only determine what a reasonable person would have done in the defendant's position, rather than what the defendant actually thought at the time of the incident).

${ }^{83}$ Harlow, 457 US at 815-17.

84 Mitchell, 472 US at 524-30. Without the interlocutory appeal, the defendant's right not to stand suit would be effectively lost because the immunity determination would come after trial. For a discussion of the interlocutory appeal issue, see Note, Qualified Immunity and Interlocutory Appeal: Is the Protection Lost When Legal and Equitable Claims are Joined?, 87 Colum L Rev 161 (1987).

ss See, for example, Scheuer v Rhodes, 416 US 232, 241-42 (1974); Harlow, 457 US at 807, 813-14; Wood v Strickland, 420 US 308, 319-20 (1975).

457 US at 814, quoting Gregoire v Biddle, 177 F2d 579, 581 (2d Cir 1949).

${ }^{87}$ See Comment, Harlow v. Fitzgerald: The Lower Courts Implement the New Standard for Qualified Immunity under Section 1983, 132 U Pa L Rev 901, 913-14 (1984).

${ }^{88}$ Harlow, 457 US at 819, citing Pierson, 386 US at 554.

89 Harlow, 457 US at 814.

${ }^{80} \mathrm{Id}$.

92 See, for example, Oren, 50 U Pitt L Rev 935 (cited in note 69); David Rudovsky, The Qualified Immunity Doctrine in the Supreme Court: Judicial Activism and the Restriction of Constitutional Rights, $138 \mathrm{U} \mathrm{Pa} \mathrm{L}$ Rev 23 (1989). 
and immunity, however, these policy concerns have informed and will continue to inform the Court's immunity jurisprudence.

\section{B. Immunity for Private Defendants in the Lower Courts}

Faced with a multitude of post-Lugar suits, lower courts have fashioned a range of private party defenses to $\S 1983$ claims. The different formulations depend on a court's willingness to import the Supreme Court's public official analysis into the private context. Essentially, three approaches have emerged from the case law: no immunity, a good faith defense, and qualified immunity.

\section{No immunity.}

A few appellate courts have maintained a steady bar against granting any immunities or defenses to $\S 1983$ private defendants. These courts have often expressed the concern that the policy underlying public officer immunity-a need to encourage public officers to perform their duties to the fullest extent without undue fear of liability-does not apply in the private immunity context.

For example, in Downs $v$ Sawtelle, ${ }^{92}$ the plaintiff alleged that the defendant, a private individual acting as the plaintiff's guardian, conspired with a local hospital, doctor, and state social workers to have her sterilized. The court refused to extend immunity to the plaintiff's guardian, warning that private party immunity would "eviscerate the fragile protection of individual liberties afforded by [§ 1983]." ${ }^{\text {"s }}$ According to the court, "[p]rivate parties simply are not confronted with the pressures of office, the often split-second decisionmaking or the constant threat of liability facing police officers, governors and other public officials." ${ }^{94}$ Although other policy considerations might support some form of immunity for private citizens, the court noted that "[w] hatever factors of policy and fairness militate in favor of extending some immunity to private parties acting in concert with state officials were resolved

\footnotetext{
92574 F2d 1 (1st Cir 1978). Downs was a pre-Lugar case, but the First Circuit does not appear willing to reconsider its holding in light of Lugar. See Lovell v One Bancorp, 878 F2d 10, 12 (1st Cir 1989) (holding that a private citizen is not entitled to interlocutory appeal of the denial of qualified immunity because the policy considerations that entitle public officials to this protection are not present for private individuals). The Lovell court did not reach the question whether a private defendant should be entitled to claim immunity protection in the first instance. Id at $13 \mathrm{n} 5$.

's Downs, 574 F2d at 15.

9 Id.
} 
by Congress in favor of those who claim a deprivation of constitutional rights."

The Ninth Circuit has also refused to recognize any immunities or defenses to $\S 1983$ suits for private defendants. In Howerton $v$ Gabica, the court did not extend immunity to defendant landlords who evicted the plaintiff without following proper eviction procedures. ${ }^{26}$ The landlords had enlisted the aid of a police officer to serve the eviction notice and later to disconnect the utilities. ${ }^{97}$ In a footnote of its own, the court construed Lugar's footnote regarding the possibility of private immunity as a mere suggestion and concluded that "there is no good faith immunity under section 1983 for private parties who act under color of state law to deprive an individual of his or her constitutional rights." ${ }^{38}$ But the court did cite Lugar as precedent for its finding that the landlords acted under color of law by "deliberately cloak[ing] themselves with the authority of the state in effecting repossession." Trotter, Inc. $v$ Watkins, the Ninth Circuit refused to extend an immunity to a private contractor which was sued for actions it took that were necessary to fulfill a land survey contract with the Navy. ${ }^{100}$

\section{Good faith defense.}

Although most courts equate "good faith defense" with "qualified immunity," the Sixth Circuit articulated a distinct good faith defense in Duncan v Peck. ${ }^{101}$ In that case, Peck sued Duncan in an Ohio state court to recover a $\$ 20,000$ debt. Peck's attorney secured a prejudgment attachment order against shares of stock located in Ohio that were owned by Duncan, who was not a resident of Ohio. The Ohio Supreme Court subsequently declared the prejudgment

${ }^{95}$ Id at 15-16. See also Judge Johnson's dissent in a 6-1-5 Eleventh Circuit opinion recognizing qualified immunity for private defendants. Judge Johnson argued that immunities should not be accorded out of a concern for protecting the person, but rather the office. Because private individuals or entities hold no office, they should not receive the protection of immunities. Jones $v$ Preuit \& Mauldin, 851 F2d 1321, 1343 (11th Cir 1988) (en banc) (Johnson dissenting), vacated on other grounds, 109 S Ct 1105 (1989).

96 708 F2d 380 (9th Cir 1983).

97 Id at 381 .

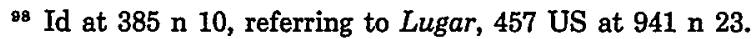

ov Id at 384-85.

100869 F2d 1312, 1318 (9th Cir 1989) (Bivens claim). Compare DeVargas $v$ Mason \& Hanger-Silas Mason Co., Inc., 844 F2d 714, 720-22 (10th Cir 1988) (Bivens and $\S 1983$ claims) (qualified immunity granted to private government contractors).

101844 F2d 1261 (6th Cir 1988). 
process unconstitutional, and Duncan brought a $\S 1983$ suit against Peck on a Lugar theory. ${ }^{102}$

Employing the Supreme Court's historical inquiry, the court suggested that private parties were not entitled to immunity at common law. ${ }^{103}$ The court did note, however, that at common law a private creditor could claim an affirmative defense based on probable cause when faced with a debtor's wrongful attachment or malicious prosecution suit. But it refused to transform this traditional defense into an immunity. ${ }^{104}$ Discussing Lugar's reference to private immunity, the court suggested that although "footnote [23] may appear on the surface to invite the extension of good faith immunity to private individuals ... a close examination of the Supreme Court's language offers the possibility of some sort of defense from liability to private individuals, and does not necessarily suggest the specific defense of immunity."105 Since the common law torts of malicious prosecution and wrongful attachment both employed a subjective standard of probable cause, which required an inquiry into the mental state of the defendant, the Duncan court adopted a subjective focus for the good faith defense. ${ }^{106}$

\section{Qualified immunity.}

The Third, Fifth, Eighth, Tenth, and Eleventh Circuits have recognized qualified immunity for private defendants and formulated similar approaches to the question by borrowing reasoning from one another. ${ }^{107}$ These courts cite the same historical evidence as Duncan, but they justify the additional step of transforming the good faith defense into an immunity on grounds of public policy. For example, in Folsom Investment Co., Inc. $v$ Moore, a prejudgment attachment case, the Fifth Circuit recognized a qualified immunity for private individuals and entities because "a citizen should not be penalized for resorting to the courts to vindicate rights he in good faith has probable cause to believe are his. . . .

${ }^{102}$ Id at $1262-63$.

103 Id at 1264.

104 Id at 1266.

${ }^{105}$ Id at 1265, referring to Lugar, 457 US at $941 \mathrm{n} 23$.

108 Id at 1267.

${ }^{207}$ Shipley v First Federal Savings \& Loan Ass'n of Del., 877 F2d 57 (3d Cir 1989), aff'g 703 F Supp 1122 (D Del 1988); DeVargas v Mason \& Hanger-Silas Mason Co., Inc., 844 F2d 714 (10th Cir 1988) (Bivens and § 1983 claims); Jones v Preuit \& Mauldin, 851 F2d 1321 (11th Cir 1988) (en banc), vacated on other grounds, $109 \mathrm{~S} \mathrm{Ct} 1105$ (1989); Buller $v$ Beuchler, 706 F2d 844 (8th Cir 1983); Folsom Investment Co., Inc. v Moore, 681 F2d 1032 (5th Cir 1982). 
Congress . . . could not have intended to subject to liability those who in good faith resorted to legal process."108

Most courts adopting qualified immunity for private defendants simply incorporate the objective good faith standard established by Harlow. An Eleventh Circuit plurality formulated the inquiry as follows: "[I]mmunity attaches unless the defendants reasonably should have known that their actions violated clearly established constitutional rights." 109 Framing the immunity inquiry as an objective test allows the court to decide the question of what a reasonable person would have done in the defendant's situation given the state of the law. This approach avoids protracted pretrial discovery and encourages expedited motions for summary judgment. ${ }^{110}$

\section{Qualified Immunity for Private Defendants UNDER SECTION 1983}

This Section proposes a formulation of qualified immunity that responds to the way in which Lugar transformed the joint participation rationale and conforms to the policy considerations underlying the Court's public officer immunity jurisprudence.

108681 F2d at 1038.

109 Jones, 851 F2d at 1324.

110 The line between good faith defense and qualified immunity has sometimes been murky, however. Some courts have announced that they are adopting qualified immunity for private individuals and entities, but then articulate a standard that includes a subjective component, a characteristic of a Duncan-style good faith defense. See, for example, Buller, $706 \mathrm{~F} 2 \mathrm{~d}$ at 851 ("There is a strong public interest in permitting private individuals to rely on presumptively valid state laws and in shielding those citizens from monetary damages where they resort to a legal process which they neither know, nor reasonably should know, is invalid.") (emphasis added). The confusion probably stems from Justice Brennan's concurrence in Harlow in which he took the majority's language from its "extraordinary circumstances" exception and identified it as the holding. See text at notes 78-79. Brennan stated that he "agree[d] with the substantive standard announced by the Court today, imposing liability when a public official defendant 'knew or should have known' of the constitutionally violative effect of his actions." 457 US at 820-21 (Brennan concurring). The Court has since reaffirmed its purely objective inquiry. See Anderson, 483 US at 639-40.

Justice Brennan's importation of a subjective component into the Harlow test was designed to address the following question: May an officer who actually knows (possesses subjective knowledge) of the existence of a constitutional right in question escape liability because a reasonable officer would not have known of it? Justice Brennan answered "no" to this hypothetical in his Harlow concurrence. 457 US at 821 (Brennan concurring). For a discussion of the issue, see Kinports, $23 \mathrm{Ga} \mathrm{L} \mathrm{Rev} \mathrm{at} \mathrm{607-18} \mathrm{(cited} \mathrm{in} \mathrm{note} \mathrm{81).}$ 


\section{A. A Qualified Immunity Formulation for Private Defendants}

1. Standard governing the merits of the claim.

A qualified immunity for private parties would adopt the Harlow objective test and translate it into the private immunity context. Private party defendants would be shielded from liability when they rely on state enactments and authority that reasonable persons would believe are valid. The exact degree of knowledge of the law that a private person or entity would be presumed to possess cannot be determined; that is a decision for the courts to make on a case-by-case basis according to the particular situation. In general, however, a business that consults regularly with an attorney would be held to a higher standard than one in which such consultation would be a novelty. ${ }^{111}$ Similarly, an officer of the state would be held to a higher standard of legal knowledge than a layperson, although both would be entitled to rely on state enactments not yet challenged in the courts. ${ }^{112}$ The objective nature of the inquiry would also enable private defendants to enjoy the same procedural benefits as public officers, including limited discovery, expedited summary judgment, and immediate appeal. ${ }^{113}$ Whether public and private immunities will develop precisely the same contours, however, is a question left for subsequent case law development. ${ }^{114}$

2. Entitlement to assert the claim.

All private defendants sued under a Lugar theory would be entitled to assert the claim to qualified immunity. This would parallel the Court's granting of an across-the-board qualified immu-

$" 1$ See, for example, Watertown Equipment Co. $v$ Norwest Bank Watertown, 830 F2d 1487, 1496 (8th Cir 1987) (holding a private bank to a relatively high standard of legal knowledge).

"12 See Carman v City of Eden Prairie, 622 F Supp 963, 967 (D Minn 1985) (noting that because no one had ever challenged the state procedure before, the private entity "had little reason, therefore, to suspect that acting pursuant to the statute would violate plaintiff's rights").

11 Two courts addressing the issue of interlocutory appeal have reached divergent results. Compare DeVargas, 844 F2d at 717 (private company that provided security inspectors to certain government entities was entitled to an immediate review of the district court's denial of immunity), with Chicago \& North Western Transp. Co. $v$ Ulery, 787 F2d 1239, $1241 \mathrm{n} 1$ (8th Cir 1986) (interlocutory appeal appropriate only in cases in which the plaintiff joins both private and public parties as defendants), and Lovell $v$ One Bancorp, 878 F2d 10, 12 (1st Cir 1989) (private defendants not entitled to interlocutory appeal).

114 See Folsom, 681 F2d at 1037 ("Whether the precise contours of the [qualified immunity] rule will develop identically, we leave to future cases."). 
nity to all public officers sued in their individual capacities and its simultaneous rejection of the historical prong of the immunity inquiry. As discussed above, the lower courts have applied the dual history/public policy inquiry in the private immunity context. But regardless of the historical inquiry's shortcomings in the public officer context, ${ }^{115}$ the historical approach is particularly ill-equipped to address questions of immunity in the private context.

The problem stems from the fact that the Court has used history to inform its analysis of the scope of immunity to $\S 1983$ liability but has neglected history when considering the scope of liability itself. In other words, the Court has limited its immunity inquiry to the common law of 1871 with one hand, while expanding liability far beyond that envisioned by the authors of $\S 1983$ with the other. ${ }^{116}$ This inconsistency has not posed a problem for public officers because they enjoyed the protection of immunities at common law. But private parties are not similarly situated. They were not entitled to immunity protection in 1871 because they had no need of it; they were not considered state actors under $\S 1983$ for another century. ${ }^{112}$ Thus, to look back at the common law for an answer to the question whether a private individual in a particular situation is entitled to claim an immunity is to answer the question before the inquiry begins.

The difficulties of the historical approach have become clear as the post-Lugar suits in the lower courts expand beyond the creditor remedy context. Not surprisingly, the first round of immunity decisions addressed factual scenarios not unlike that in Lugar. These courts readily used the common law to justify their decisions allowing private creditors to assent an immunity claim. For example, the court in Buller $v$ Beuchler drew support for the immunity from the common law tort of malicious prosecution, which "could be used as a remedy for attachment proceedings wrongfully commenced when the plaintiff could prove that those proceedings were instituted with malice and without probable cause."118 But such common law analogs are not easily expanded to other contexts.

118 See text at notes 64-70.

${ }_{118}$ See Note, Qualified Immunity for Civil Rights Violations: Refining the Standard, 75 Cornell L Rev 462, 465 (1990) ("Since [Monroe v Pape], lower courts have permitted use of Section 1983 to remedy a wide variety of constitutional violations far beyond the original, limited purposes of the [Civil Rights Act of 1871].").

117 See Adickes v S.H. Kress \& Co., 398 US 144 (1970).

$118706 \mathrm{~F} 2 \mathrm{~d}$ at 851. 
A case in point is Carman $v$ City of Eden Prairie, in which the plaintiff was arrested and charged with driving while intoxicated. ${ }^{119}$ After his arrest, the plaintiff was taken to a private statelicensed detoxification center pursuant to the state's "obligatory hold" procedure, under which publicly intoxicated persons receive emergency treatment and counseling at local hospitals. The plaintiff, who was released from the center the day after his arrest, claimed the center deprived him of his liberty without due process. In affording qualified immunity to the defendant, the court did not make an inquiry into the common law immunities of 1871 regarding the liability of hospitals when they treat patients for public intoxication; instead, it based its decision on the "strong public interest in permitting private individuals to rely on presumptively valid state laws and in shielding those citizens from monetary damages . . .."120

This ahistorical approach would be consistent with the Court's reformulation of public officer immunity and would preserve the holding of Dennis $v$ Sparks. It would cast doubt on that case's rationale, however. When the Dennis Court faced the question of private party immunity, it utilized the historical approach in rejecting the defendants' claim, noting that they had "pointed to nothing indicating that, historically, judicial immunity insulated from damages liability those private persons who corruptly conspire with the judge."121 Denying immunity was the "right" result on those facts, but the method by which it was reached will not be of much comfort to post-Lugar private defendants who deserve the protection of an immunity defense when they act in good faith but who are unable to find a common law analog to their immunity claim.

\section{B. The Case for Qualified Immunity}

This qualified immunity formulation is an appropriate response to the post-Lugar state action landscape and is consistent with the policies underlying the Court's public officer immunity jurisprudence. Lugar significantly transformed the nature and function of the joint participation doctrine when it shifted the burden of presenting the issue of intent from the prima facie claim to the defense. To accomplish the shift, the Court jettisoned the conspiracy requirement, thus allowing a cause of action against defend-

119622 F Supp 963 (D Minn 1985).

120 Id at 966, citing Buller, $706 \mathrm{F2d}$ at 851.

121449 US at 29. 
ants who knew they were violating the plaintiff's clearly established rights as well as against those who did not. The Court then suggested that qualified immunity would provide the sorting mechanism between the two groups, placing the burden of operating the mechanism on the defendants. Thus, Lugar was written with the qualified immunity escape hatch in mind. ${ }^{122}$

Courts that have denied private party immunity suggest that private individuals and entities do not operate under the same constraints as public officials. ${ }^{123}$ Although the policy justifications underlying official immunity do not precisely mirror those underlying private immunity, they do take aim at a similar target. Just as public officers should be able to execute their legitimate duties without undue fear of liability, so too should average citizens and businesses be able to rely on presumptively valid state statutes or authority to vindicate their rights or to fulfill their obligations. For example, in Howerton $v$ Gabica, ${ }^{124}$ the defendant landlords had the legal right to call the police officers to their aid in the eviction procedure-as long as they were acting in good faith. The defendants in F.E. Trotter, Inc. $v$ Watkins ${ }^{125}$ were under a legal obligation to complete their contract with the Navy to survey the land. And the hospital in Carman ${ }^{126}$ followed the obligatory hold procedure to the letter with regard to the intoxicated plaintiff. After Lugar, however, these rights and duties can be adequately vindicated only through an entitlement to qualified immunity.

Indeed, attaching liability to good faith private defendants creates an incentive for private parties to avoid $\S 1983$ liability by refusing to invoke any government authority at all. Courts should encourage private parties to settle their differences through the employment of legal mechanisms they in good faith believe are constitutional instead of resorting to less desirable methods of selfhelp. ${ }^{127}$ Lugar itself suggested that private parties have a right "to rely on some state rule governing their interactions with the community surrounding them." ${ }^{128}$ And as one court noted, "[w] hat we encourage we ought not seek to punish."129

122 This inference is even stronger given that the Court handed down Harlow on June 24 and Lugar the next day.

${ }^{123}$ See text at notes $92-100$.

124708 F2d 380 (9th $\mathrm{Cir} 1983$ ). For a discussion of the case, see text at notes 96-99.

128869 F2d 1312 (9th Cir 1989). See text at note 100.

${ }^{126} 622$ F Supp 963 (D Minn 1985). See text at notes 119-20.

127 See Jones, 851 F2d at 1325.

${ }^{128}$ Lugar, 457 US at 937.

129 Jones, $851 \mathrm{~F} 2 \mathrm{~d}$ at 1325. 
An additional concern is that the state, not private parties, should be liable for unconstitutional laws or official misbehavior. To allow the legislature to act unconstitutionally while simultaneously placing the full burden of compensating the victims of the unconstitutional acts on private defendants violates fundamental principles of political accountability. ${ }^{130}$ Indeed, the Lugar Court was willing to protect the government from liability for private conduct that it did not initiate. In addressing the justifications for the state action doctrine, the Lugar majority noted that it "avoids imposing on the State, its agencies or officials, responsibility for conduct for which they cannot fairly be blamed."131 That the Court should accord private persons similar protection seems only logical.

The logic of extending this protection to private individuals may be apparent, but courts have correctly recognized that neither precedent nor common law history provides a basis for development of private party immunities. One judge characterized the creation of immunities for private parties as a "striking display of judicial activism."132 This is undoubtedly true. Yet this criticism ignores the fact that the creation of immunities is a response to the original "activism" of extending $\S 1983$ liability into the realm of formerly protected private conduct. Allowing private actors to claim an immunity defense merely completes the state action fiction that treats private entities like the Edmondson Oil Company as officers of the state. Indeed, it would be inconsistent to hold private individuals and entities liable as state actors but deny them the qualified immunity possessed by the state officials with whom they dealt because they technically are not state employees. ${ }^{133}$ Treating private entities as state actors for liability and not for immunity creates a flawed asymmetry, flouting notions of private autonomy and choice that form the core of the state action doctrine.

Finally, qualified immunity still allows the courts to attach liability to conspiratorial conduct; it preserves the holdings in cases such as Dennis and Adickes. Defendants who intentionally violate clearly established law would be entitled to claim an immunity, but their claims would not succeed on the merits. In other words, where private defendants reasonably should have known that their reliance on state statutes or authority would violate clearly estab-

\footnotetext{
1so Folsom, 681 F2d at 1037.

131 Lugar, 457 US at 936.

132 Jones, 851 F2d at 1341 (Vance dissenting).

13s Buller, $706 \mathrm{~F} 2 \mathrm{~d}$ at 851.
} 
lished law, they would fail the qualified immunity test. ${ }^{134}$ As the Eleventh Circuit suggested in Jones, "[qualified immunity] preserves the full deterrent force of section 1983 by excluding from liability only those who could not reasonably have known that their conduct violated the federal constitution. No additional deterrence can be achieved by punishing individuals who could not reasonably have known that their actions were improper."135 Thus, qualified immunity comports with the twin concerns of $\S 1983$ : deterrence and compensation. ${ }^{\text {136 }}$

\section{ConcLusion}

In Lugar, the Court significantly reformulated the joint participation rationale of state action, jettisoning the requirement of conspiracy and exposing good faith defendants to suit. After Lugar, the plaintiff need not show conspiratorial intent; instead, the defendant must show he acted in good faith. This shift in the burden of presenting intent marked a significant change in the nature of $\S 1983$ inquiry. Prior to Lugar, the conspiracy requirement of the prima facie case shielded good faith defendants from liability. After Lugar, private party immunities must perform this critical function. Thus, the focus must necessarily turn from the state action to the immunity side of the equation.

The Supreme Court's immunity analysis for public officers is the logical source from which to derive a private party immunity that responds to the ways Lugar changed the state action landscape. In Harlow, the Court revised its immunity analysis by adopting a purely objective test to shield from liability those defendants who did not violate clearly established rights of which a reasonable person would have known. The Court's reformulation of the immunity analysis from an objective/subjective hybrid test to a purely objective test was prompted by its concern that the threat of frivolous suits would deter public officers from vigorously executing their duties. The objective nature of the Harlow inquiry allows courts to decide whether the constitutional right is "clearly established" as a matter of law, thus facilitating expedited sum-

334 See Nahmod, Civil Rights Litigation $\$ 2.10$ at 103 (cited in note 12). For example, the First Circuit recently implied that granting immunity to private persons, especially those acting to maximize profit, might encourage unconstitutional deprivations of fundamental rights. Lovell $v$ One Bancorp, 878 F2d 10 (1st Cir 1989). But under the qualified immunity doctrine, these commercial actors would escape liability only if they could show that a reasonable person would not have acted otherwise.

13s 851 F2d at 1325 .

${ }^{138}$ See text at notes 10-11. 
mary judgment on the immunity issue, early disposal of frivolous lawsuits, and immediate appeal of immunity denials. The objective test also allows courts to limit discovery because the particular official's intent-whether he actually knew that his conduct violated clearly established constitutional rights-is no longer an issue in all but the exceptional cases.

Private individuals and entities sued under Lugar should be entitled to a qualified immunity for acts taken in good faith. Just as a public officer must not be deterred by undue fear of frivolous litigation, a private individual must be able to rely on presumptively valid state enactments and legitimate state authority. Attaching liability to good faith conduct creates an incentive for private individuals to resort to less desirable methods of self-help. An entitlement to the full benefits of qualified immunity would address this concern as well as respond to the Lugar formulation of the joint participation rationale. 


$$
-
$$

